\title{
The Synthesis of $\beta$-Galactosidase by Constitutive and Other Regulatory Mutants of Escherichia coli in Chemostat Culture
}

\author{
By CLAIRE J. L. MACLEOD, P. DUNNILL AND M. D. LILLY \\ Biochemical Engineering Section, Department of Chemical Engineering, \\ University College London, London $W_{\mathrm{I}} E_{7} J E$
}

(Received 3I October 1974; revised 2I March 1975)

\begin{abstract}
SUMMARY
The synthesis of $\beta$-galactosidase by an $E$. coli constitutive mutant was examined in a chemostat using glucose-, glycerol-, succinate- or $\mathrm{N}$-limited growth media. Except for glucose-grown bacteria, the steady-state intracellular level of $\beta$-galactosidase was maximal at dilution rates between 0.2 and $0.3 \mathrm{~h}^{-1}$. At higher dilution rates enzyme synthesis was reduced by catabolite repression, which could be relieved by the addition of cyclic AMP. With a catabolite-resistant mutant (UV5c), no decrease in enzyme level at high dilution rates was observed. All mutants examined were constitutive and gave decreased enzyme levels at low dilution rates, with the exception of $l a c^{-} / \mathrm{F}^{\prime} l a c$ UV5c mutants where the enzyme levels rose at low dilution rates. Hyper-producing mutants were isolated but were unstable. A constitutive mutant growing on glycerol-limited media was considered the most suitable for large-scale production of $\beta$-galactosidase in a chemostat.
\end{abstract}

\section{INTRODUCTION}

Enzyme synthesis in bacteria has been the subject of two major review articles (Pardee, I969; Demain, I97I), which included methods of increasing enzyme yields by specific genetic and environmental manipulations. However, there has been little experimental data published on the application of these concepts to the production of intracellular enzymes.

The regulation of enzyme synthesis has generally been studied using batch cultures of exponentially growing bacteria and there have been comparatively few studies of enzyme regulation in the chemostat. Dean (1972) reviewed the control of enzyme synthesis in the chemostat, dividing the enzymes into four classes depending on whether the specific enzyme activity in a steady state increased, decreased, or passed through a maximum or minimum with increasing growth rate. However, the rates of synthesis of an enzyme may fall into different categories with different limiting substrates or with the introduction of certain classes of mutations. Specific enzyme activities vary markedly with growth rate and there have been few explanations of why the intracellular levels of catabolic enzymes vary so widely over small ranges in growth rate.

Clarke, Houldsworth \& Lilly (1968) studied the control of synthesis of the aliphatic amidase of Pseudomonas aeruginosa 8602 (now PACI) in a chemostat. Amidase is induced in the presence of the substrate, acetamide, and is subject to catabolite repression. Wild-type $P$. deruginosa and various regulatory mutants were grown in the chemostat in separate experiments. Each mutant had a different and characteristic profile of amidase activity with dilution rate. Clarke et al. (1968) concluded that under steady-state conditions the specific activity of the amidase is determined by the balance between induction and catabolite repression, and that catabolite repression is directly related to the growth rate of the culture. 
Here we describe the synthesis of $\beta$-galactosidase by various mutants of Escherichia coli in a chemostat. Our objective was to find the best mutant for production of $\beta$-galactosidase in a 10001 chemostat supplying a continuous flow isolation process (Gray, Dunnill \& Lilly, 1972). During the development of this process a constitutive mutant, ML308, was used and its behaviour in a chemostat is described here. We have also looked at the possibility of using hyper-producing mutants and catabolite-insensitive mutants with another strain, CA8.000, since they were not readily available for strain ML308.

\section{METHODS}

Organisms. The following strains were used: E. coli ML308 (NCIB9553), a fully constitutive $\beta$-galactosidase mutant; wild-type $E$. coli CA8.000 (from $\mathrm{Dr}$ J. R. Beckwith), and the derivatives $E$. coli lac Uv5 (from Professor B. Magasanik), E. coli lac ${ }^{-} / \mathrm{F}^{\prime} l a c$ Uv5 and $E$. coli lac ${ }^{-}$pro- $/ \mathrm{F}^{\prime}$ lac Uv5 $\mathrm{pro}^{+}$(from Drs J. Scaife and A. E. Silverstone), all with inducible episomal lac operons but insensitive to catabolite repression. Constitutive lac mutants were constructed from $E$. coli $\mathrm{CA} 8.000$ and its three regulatory mutants by treatment with nitrosoguanidine $(200 \mu \mathrm{g} / \mathrm{ml})$ and selection on sodium lactobionate media (Langridge, 1969). These were designated $E$. coli $\mathrm{cA8} 8000 \mathrm{c}$, lac uv5c, lac $/ \mathrm{F}^{\prime} l a c$ uv5c, and $l a c^{-}$pro- $/ \mathrm{F}^{\prime} l a c$ UV5c pro $^{+}$respectively. For strains where the lac gene was believed to be episomal, this was confirmed by their loss of ability to utilize lactose after growth in nutrient broth containing acridine orange $(200 \mu \mathrm{g} / \mathrm{ml})$. Escherichia coli $\mathbf{B}$ was also used to select hyper-producing strains. The organisms were maintained on nutrient agar slopes stored at $4{ }^{\circ} \mathrm{C}$.

Media. For growth of strain ML308, the minimal salts medium contained $(\mathrm{g} / \mathrm{l}):\left(\mathrm{NH}_{4}\right)_{2} \mathrm{SO}_{4}$, 5; $\mathrm{NaCl}, 3 ; \mathrm{Na}_{2} \mathrm{HPO}_{4}, 5.4 ; \mathrm{KH}_{2} \mathrm{PO}_{4}, \mathrm{I} \cdot 6 ; \mathrm{MgSO}_{4} \cdot 7 \mathrm{H}_{2} \mathrm{O}, 0 \cdot \mathrm{I}$; plus carbon source as indicated in Results. In the N-limited medium the $\left(\mathrm{NH}_{4}\right)_{2} \mathrm{SO}_{4}$ concentration was reduced to $0.45 \mathrm{~g} / \mathrm{l}$. With the exception of glucose and lactose which were sterilized separately, the carbon source was added to the medium before sterilization by steam under pressure.

For all other strains tryptone $(0.2 \mathrm{~g} / \mathrm{l})$ and aneurine hydrochloride $(0.0 \mathrm{I} \mathrm{g} / \mathrm{l})$, sterilized by filtration using a Millipore membrane $(0.22 \mu \mathrm{m}$ pore size), were added aseptically to the steam-sterilized medium. Sterile PPG 2000 antifoam (Shell Chemical Ltd) was also added at $0.05 \mathrm{ml} / 1$.

Growth. The bacteria were grown at $37^{\circ} \mathrm{C}$ in three different continuous culture vessels. For measurements of steady-state enzyme levels with strain ML308, a 51 Porton-type fermenter containing 31 medium was used. The culture was maintained at $\mathrm{pH} 70^{\circ} \mathrm{O}$ by the automatic addition of either $2 \mathrm{M}-\mathrm{HCl}$ or $2 \mathrm{M}-\mathrm{NaOH}$. Sterile air was supplied at $\mathrm{I} 1 / \mathrm{min}$ through a sparge pipe placed under a turbine impeller rotating at $\mathrm{I} 4 \mathrm{rev}$./s. Culture left the vessel down a shielded overflow pipe into a collecting vessel. Samples (5 to $10 \mathrm{ml}$ ) were withdrawn through a narrow-bore tube leading to a sterile bottle.

For experiments with strain ML308 involving cyclic AMP (c-AMP) and for selection of some hyper-producing strains, a smaller glass vessel containing $50 \mathrm{ml}$ medium was used. Moist air was supplied at $250 \mathrm{ml} / \mathrm{min}$ through a sintered-glass sparger and the medium stirred vigorously with a polythene-coated bar magnet driven by an external magnetic stirrer. Samples were either collected from the overflow or (for rapid non-aseptic sampling) through a top port using a syringe and fine nylon tube.

For measurements of steady-state enzyme levels, strain CA8.00oc and its derivatives were grown in a Bioflo model $\mathrm{C}_{3}$ o continuous culture apparatus (New Brunswick Scientific Co.). The liquid volume was $250 \mathrm{ml}$ and the air flow rate was $300 \mathrm{ml} / \mathrm{min}$.

Cultures were considered to be in a steady state after $24 \mathrm{~h}$ at a dilution rate greater than 
$0.15 \mathrm{~h}^{-1}$. At lower dilution rates $48 \mathrm{~h}$ were allowed before samples were taken. At least three samples were taken at each steady-state value and measurements on each sample were done in quadruplicate. Culture purity was checked daily by plating $0.01 \mathrm{ml}$ on a nutrient agar plate.

Measurements. Bacterial concentrations were determined by measurement of the extinction of suspensions at $670 \mathrm{~nm}$ with a $10 \mathrm{~mm}$ light path. Below an extinction of 0.5 , the bacterial concentration $(\mathrm{mg}$ dry $\mathrm{wt} / \mathrm{ml})$ was equal to $0.5 \mathrm{I} \times$ extinction value.

The $\beta$-galactosidase activities of bacteria were assayed by measuring the rate of hydrolysis of $o$-nitrophenylgalactoside using the method originally described by Lederberg (1950) and expressed as $\mu \mathrm{mol} o$-nitrophenol formed/min. Specific activities were calculated as $\mu \mathrm{mol} /$ $\mathrm{min} / \mathrm{mg}$ dry wt bacteria. The maximum difference between duplicate assays was less than $5 \%$.

\section{RESULTS}

\section{$\beta$-Galactosidase activities of E. coli ML308 growing under steady-state conditions}

When E. coli ML308 was grown in a chemostat, regular oscillations in the culture enzyme activity were observed even after steady-state conditions were reached (Fig. I). The periodicity of the oscillations was about $\mathrm{I} h$ and the amplitude was $20 \%$ of the mean value. There was no significant variation in the bacterial concentration. In all other experiments where steady-state enzyme activities were required, at least three samples were taken over a period of about $2 \mathrm{~h}$ and the stated activities are the arithmetic mean.

Steady-state enzyme specific activities were measured in chemostat cultures on three different C-limited media between dilution rates $(D)$ of 0.03 and $0.6 \mathrm{~h}^{-1}$ (Fig. 2). The growth yields (g dry wt bacteria/g nutrient) were 0.49 for glycerol, 0.49 for glucose and 0.24 for succinate (as succinic acid) in the dilution range 0.1 to $0.4 \mathrm{~h}^{-1}$. At lower and higher dilution rates the growth yields were reduced. It was not possible to obtain reliable steadystate enzyme activity values for bacteria where the growth-limiting component was lactose. The effect of glycerol feed concentration on the specific activities of $\mathrm{C}$-limited bacteria was measured (Fig. 3). With a glycerol feed of $10 \mathrm{~g} / \mathrm{l}$ the specific activities at high dilution rates were greater than for $2 \mathrm{~g} / \mathrm{l}$ (broken line), shifting the maximum value of the specific activity from $D=0.2 \mathrm{I} \mathrm{h}^{-1}$ to $D=0.26 \mathrm{~h}^{-1}$. When the medium was $\mathrm{N}$-limited with glycerol as carbon source the specific activity profile was shifted to a higher dilution rate than for carbon limitation (Fig. 3). The growth yield was $8.6 \mathrm{~g}$ dry wt bacteria/g nitrogen for $D=0.2$ to $0.4 \mathrm{~h}^{-1}$, but increased to 14.0 at lower dilution rates.

\section{The effect of adding c-AMP to steady-state cultures of E. coli ML308}

We found that in batch culture, catabolite repression of $\beta$-galactosidase synthesis in ML308 growing on glucose-6-phosphate was relieved by the addition of 10 mM-c-AMP. Thus if the synthesis of $\beta$-galactosidase in bacteria growing in a chemostat is subject to catabolite repression, addition of c-AMP to the culture should produce an increase in the enzyme specific activity. At $D=0.40 \mathrm{~h}^{-1}$ the addition of $12 \mathrm{mM}-\mathrm{c}$-AMP to the culture caused an increase of almost $50 \%$ in the enzyme specific activity for over an hour (Fig. $4 a$ ) but at a lower dilution rate $\left(D=0.12 \mathrm{~h}^{-1}\right)$ there was no effect (Fig. $\left.4 b\right)$. In both cases there was no change in bacterial concentration during the experiment. Where AMP was added to a culture growing at $D=0.40 \mathrm{~h}^{-1}$, no change was observed in enzyme specific activity. In another experiment at $D=0.40 \mathrm{~h}^{-1}$ when c-AMP was added to the feed reservoir and not the culture vessel, the specific activity decreased gradually over the next $3 \mathrm{~h}$. 


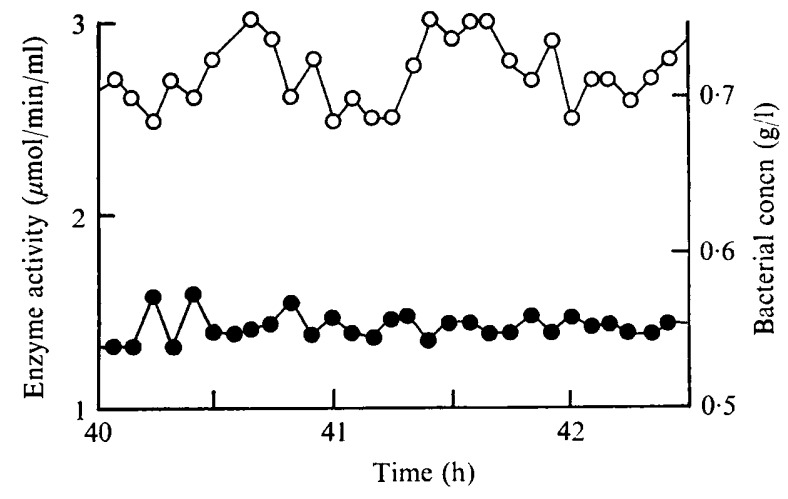

Fig. I. Variation in enzyme activity $(O)$ and concentration ( $)$ of cultures of $E$. coli ML 308 growing under glycerol-limited ( $\mathrm{g} / \mathrm{l})$ steady-state conditions after $40 \mathrm{~h}$ in a chemostat $\left(D=0.4 \mathrm{~h}^{-1}\right)$.

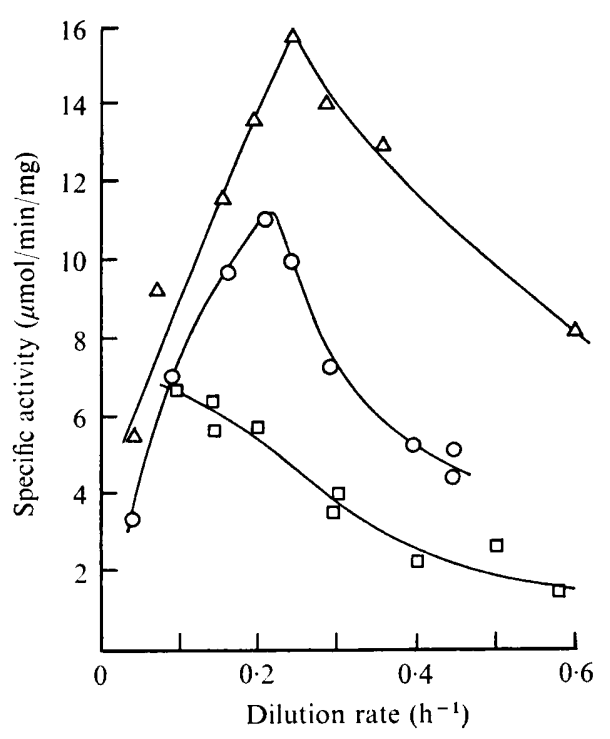

Fig. 2

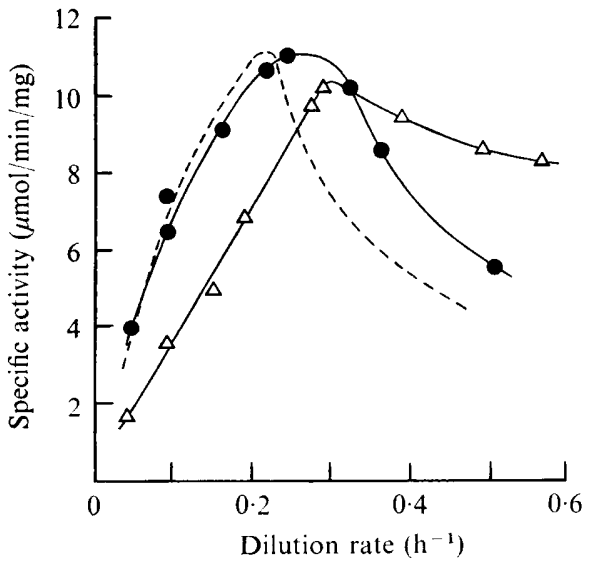

Fig. 3

Fig. 2. The effect of dilution rate on the $\beta$-galactosidase activity of $E$. coli ML308 growing under steady-state conditions in a chemostat. Growth-limiting component $(\mathrm{g} / \mathrm{l}): \triangle$, sodium succinate (1); $\bigcirc$, glycerol, (2); $\square$, glucose (I-8).

Fig. 3. The effect of $\mathrm{N}$-limitation $(\triangle)$ and $\mathrm{C}$-limitation (O) on the $\beta$-galactosidase activity of $E$. coli ML308 growing under steady-state conditions. The feed concentrations $(\mathrm{g} / \mathrm{l})$ of ammonium sulphate and glycerol were 0.45 and 4.0 for N-limited growth and 5.0 and 10.0 for C-limited growth. The broken curve shows the results for C-limited growth with $2 \mathrm{~g}$ glycerol/1 (taken from Fig. 2).

\section{$\beta$-galactosidase production by hyper-producing mutants}

Escherichia coli B was used, since Vojtíšek, Sikyta \& Slezák (1969) reported it gave the best hyper-mutants. After 3 days of growth in the $50 \mathrm{ml}$ chemostat on lactose-limited medium $(0.2 \mathrm{~g} / \mathrm{l})$ at $D=0.5 \mathrm{~h}^{-1}$, the activity of the culture rose slowly from 12 to $20 \mu \mathrm{mol} /$ $\mathrm{min} / \mathrm{mg}$ bacteria and then remained stable. When the concentration of lactose in the medium was raised to $0.5 \mathrm{~g} / \mathrm{l}$, the bacterial concentration increased as expected but the $\beta$-galactosidase activity fell to $4 \cdot 2 \mu \mathrm{mol} / \mathrm{min} / \mathrm{mg}$. 

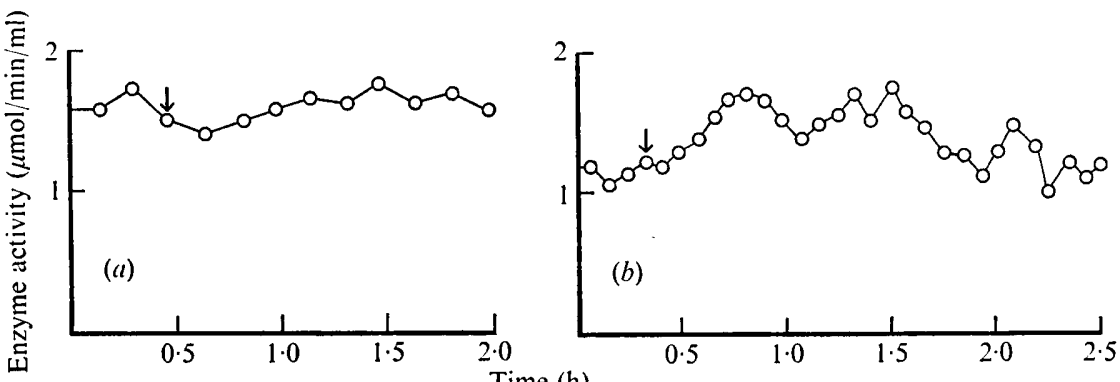

Fig. 4. The effect of rapid addition of c-AMP to cultures of $E$. coli growing under glycerol-limited steady-state conditions in a chemostat. Cyclic-AMP was added at the point shown by the arrow, to give a concentration of $12 \mathrm{~mm}$ in the culture. The $\beta$-galactosidase activities of the cells are shown for (a) $D=0.4 \mathrm{~h}^{-1}$ and (b) $D=0.12 \mathrm{~h}^{-1}$.

During growth of strain ML308 in the Bioflo fermenter on a lactose-limited medium (I $\mathrm{g} / \mathrm{l}$ ), hyper strains arose spontaneously after 5 days or less. These had a $\beta$-galactosidase activity of $38 \mu \mathrm{mol} / \mathrm{min} / \mathrm{mg}$. After a further 6 days a superhyper strain appeared with an activity of $56 \mu \mathrm{mol} / \mathrm{min} / \mathrm{mg}$. Unfortunately, when these hyper strains were used to re-start the chemostat, reversion to the constitutive strain occurred.

\section{$\beta$-galactosidase activities of $E$. coli $\mathrm{CA} 8.000 \mathrm{c}$ and its derivatives}

Catabolite-insensitive mutants of strain ML308 were not available. It was necessary therefore to change to strain CA8.000 where catabolite-insensitive mutants have been well characterized. After mutagenesis, strains with episomal lac genes were checked to ensure that the lac gene was still episomal. In both cases, treatment with acridine orange yielded lac ${ }^{-}$cultures.

The differential rates of $\beta$-galactosidase synthesis of the inducible and constitutive mutants of strain CA8.000 and its derivatives were measured in batch cultures growing exponentially on glucose or glycerol in the presence or absence of $5 \times 1 \mathrm{IO}^{-4} \mathrm{M}$-isopropyl$\beta$-D-thiogalactoside (IPTG) (Table I). The values for strain ML308 growing in the absence of IPTG on glucose or glycerol were 3.6 and $14 \cdot 6$, respectively. These results confirm that the mutants we isolated were fully constitutive and had unaltered rates of enzyme synthesis.

The steady-state enzyme specific activities of the constitutive strains CA8.000c and UV5c

Table I. Comparison between differential rates of $\beta$-galactosidase synthesis by inducible and constitutive mutants of $E$. coli $\mathrm{CA} 8.000$ and its derivative strains growing at $37^{\circ} \mathrm{C}$ in batch culture on glucose or glycerol (I $g / l$ )

IPTG (final concentration $5 \times 10^{-4} \mathrm{M}$ ) was added to cultures of inducible strains.

\begin{tabular}{|c|c|c|c|c|}
\hline & \multicolumn{4}{|c|}{$\begin{array}{l}\text { Differential rate of enzyme synthesis } \\
\qquad(\mu \mathrm{mol} / \mathrm{min} / \mathrm{mg} \text { dry } \mathrm{wt})\end{array}$} \\
\hline & \multicolumn{2}{|c|}{ Glucose } & \multicolumn{2}{|c|}{ Glycerol } \\
\hline & Inducible & Constitutive & Inducible & Constitutiv \\
\hline \multicolumn{5}{|l|}{ Strain } \\
\hline CA8.000 & 0.92 & 0.88 & $12 \cdot I$ & $12 \cdot 3$ \\
\hline UV5 & $6 \cdot 0$ & $5 \cdot 9$ & $6 \cdot 4$ & $6 \cdot 7$ \\
\hline lac-/F'UV5 & $6 \cdot 1$ & $6 \cdot 2$ & $6 \cdot 3$ & $6 \cdot 5$ \\
\hline lac $^{-}$pro $^{-} / \mathrm{F}^{\prime} \mathrm{Uv} 5$ pro $^{+}$ & $5 \cdot 7$ & $5 \cdot 9$ & $6 \cdot 6$ & $6 \cdot 2$ \\
\hline
\end{tabular}




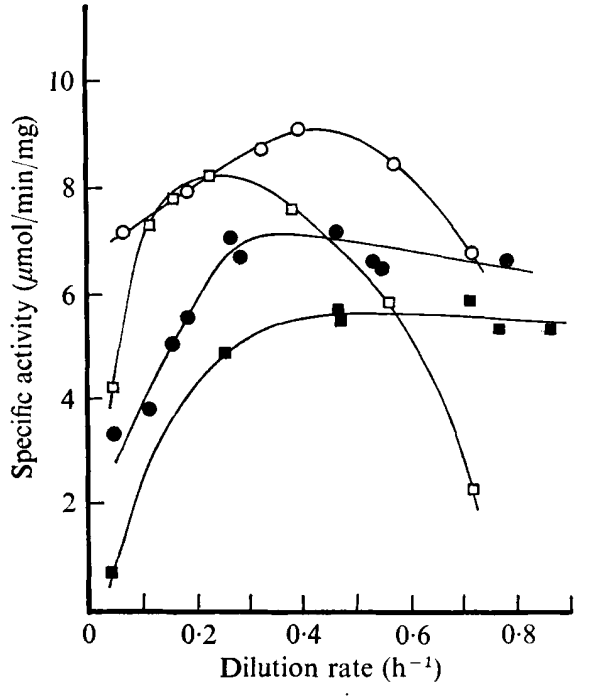

Fig. 5

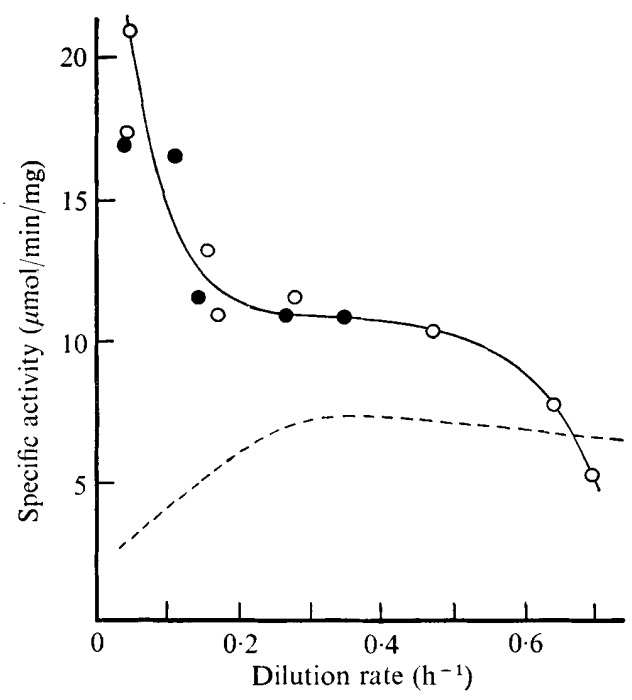

Fig. 6

Fig. 5. The effect of dilution rate on the $\beta$-galactosidase activities of strains CA8.00oc (open symbols) and UV5c (closed symbols) growing under steady-state conditions in a chemostat. Growth-limiting component ( $\mathrm{g} / \mathrm{l}$ ): $\bigcirc$, glycerol; $\square, \square$, glucose.

Fig. 6. The effect of dilution rate on the $\beta$-galactosidase activities of strains $l a c^{-} / \mathrm{F}^{\prime}$ Uv5c $(\bigcirc)$ and $l a c^{-}$ pro $^{-} / \mathrm{F}^{\prime} \mathrm{Uv}_{5 \mathrm{c}}$ pro $^{+}(\mathrm{O})$ growing under glycerol-limited ( $\left.\mathrm{g} / \mathrm{l}\right)$ steady-state conditions in a chemostat. For comparison, the broken line shows the results for strain UV5c under identical conditions (taken from Fig. 5).

growing under glucose- or glycerol-limited conditions were measured at various dilution rates (Fig. 5). At the end of the experiment with strain Uv5c, the culture was checked for insensitivity to catabolite repression by growth in batch culture on glucose or glycerol.

During chemostat operation strain UV5c was stable and never reverted to lac $^{-}$or inducible lac. However, when strain $l a c^{-} / \mathrm{F}^{\prime} \mathrm{UV} 5 \mathrm{c}$ was grown in the chemostat with glucose limitation, the culture had lost all its $\beta$-galactosidase activity after $48 \mathrm{~h}$. This did not occur with the lac ${ }^{-}$pro $^{-} / \mathrm{F}^{\prime} \mathrm{Uv} 5 \mathrm{c}$ pro $^{+}$mutant. The steady-state enzyme activities for these two strains growing under glycerol-limited conditions are shown in Fig. 6.

\section{DISCUSSION}

The objective of this work was to examine the behaviour of various regulatory mutants of $E$. coli for the production of $\beta$-galactosidase in chemostat culture. Growth of the constitutive mutant ML308 on a lactose-limited medium gave erratic results, and other carbon sources were examined. Although growth on succinate gave the highest enzyme specific activity, the growth yield was much lower than for glycerol, which is also a much cheaper carbon source.

The steady-state values of $\beta$-galactosidase activity at $D=0.40 \mathrm{~h}^{-1}$ showed regular oscillations in $\beta$-galactosidase activity with a periodicity of 60 to $70 \mathrm{~min}$ (Fig. I). Oscillations of $\beta$-galactosidase activities have been reported previously (Knorre, I969; Goodwin, 1969). In both studies the chemostat cultures were essentially unstable and not really comparable. It is always assumed that bacteria growing in a chemostat are growing asynchronously so that periodic synthesis, due to division, should not occur. If the medium is not properly 
buffered or if the cells produce a growth-inhibitory substance, the culture could become partially synchronous (Günther, Knorre \& Bergter, 1969). Behaviour of this kind would affect both bacterial and enzyme concentration and this did not occur in our experiments. The oscillating levels of $\beta$-galactosidase when c-AMP was added to the chemostat, at $D=0.40 \mathrm{~h}^{-1}$, may reflect an imbalance in metabolism since c-AMP addition may affect the rates of synthesis of other enzymes.

Since E. coli ML308 and CA8.00oc produce $\beta$-galactosidase constitutively, catabolite repression might be expected to be their only genetic regulatory control. In chemostat cultures in which growth was limited by glycerol, glucose or succinate (for ML308) the steadystate $\beta$-galactosidase specific activities decreased at high growth rates. Clarke et al. (I968) showed that there was a decrease in the steady-state amidase activity of $P$. aeruginosa PACI in chemostat cultures as growth rate was increased. This was ascribed to catabolite repression at the higher growth rates. A mutant resistant to catabolite repression was much less affected in amidase activity at corresponding growth rates. We have now observed a similar effect with a catabolite-insensitive mutant of $E$. coli $\mathrm{CA} 8.000 \mathrm{c}$, which had an almost constant $\beta$-galactosidase activity at $D>0.3 \mathrm{~h}^{-1}$. Catabolite repression also appears to be the main form of control at higher growth rates of $\beta$-galactosidase synthesis from $E$. coli ML 308 . Cyclic-AMP (I mM) will overcome transient repression of the lac genes in exponentially growing batch cultures of E. coli 3000 growing on glucose, whereas higher c-AMP concentrations $(\geqslant 5 \mathrm{mM}$ ) are needed to relieve permanent catabolite repression effects (Perlman, de Crombrugghe \& Pastan, 1969). When a c-AMP solution was added to the culture growing in a steady state at $D=0.40 \mathrm{~h}^{-1}$ on glycerol to give a concentration of $\mathrm{I} 2 \mathrm{mM}$, the $\beta$-galactosidase level rapidly increased. This effect was specific for c-AMP since when AMP was added under identical conditions there was no effect on the $\beta$-galactosidase concentration. When the c-AMP concentration was allowed to increase slowly in the chemostat, the $\beta$ galactosidase specific activity of the bacteria declined. It is possible that the ingoing c-AMP was being hydrolysed by the bacteria, but this repression of $\beta$-galactosidase activity was unexpected.

At low dilution rates, the $\beta$-galactosidase specific activities of all strains except those with episomal lac genes were depressed. Lower activities at low dilution rates were observed for the inducible enzymes, aliphatic amidase (Clarke et al. 1968) and pullulanase (Dean, 1972), and were attributed to the low effective level of inducer at these dilution rates. With a constitutive mutant producing $\beta$-galactosidase gratuitously, this cannot be the reason. CyclicAMP did not enhance enzyme activity at $D=0 \cdot 12 \mathrm{~h}^{-1}$, indicating that the low activity was not due to low intracellular c-AMP concentration. One possibility is that at low dilution rates there is a rapid turnover of $\beta$-galactosidase since the enzyme is not required, but when samples were removed from the chemostat the enzyme level did not decrease for several hours. It seems therefore that the gratuitous synthesis of $\beta$-galactosidase at low dilution rates must be restricted by the supply of components for its synthesis.

Where the lac gene was episomal the $\beta$-galactosidase specific activities were not decreased at low dilution rates. Even at high dilution rates the steady-state values for these mutants growing on glycerol were higher than for mutant Uv5c. In batch culture (Table I) there was no difference between the rates of synthesis in these mutants, but there is some evidence that genes carried episomally are more productive than genes integrated in the chromosome (Cassio, Lawrence \& Lawrence, 1970; Stetson \& Somerville, 197I). The higher activities of the mutants with episomal lac genes, especially at low dilution rates, may be due to the presence of more than one episome/bacterium (Clowes, 1972; Kontomichalou, Mitani \& Clowes, 1970). 
In this paper we have investigated various regulatory mutants for $\beta$-galactosidase production. Unless a chemostat is going to be operated for long periods, the time taken to produce hyper-mutants makes them unsuitable, especially since the enzyme specific activity fell as the bacterial concentration was increased. The catabolite-insensitive mutant, Uv5c, obtained by a double mutation in the promoter region (Silverstone, Arditti \& Magasanik, 1970) has a reduced maximal rate of $\beta$-galactosidase synthesis. This mutant therefore gave lower values of enzyme activity than the constitutive mutant, CA8.000c, at all dilution rates when grown on glycerol. The episomal lac mutants gave specific activities at low dilution rates almost twice the maximum values for strains ML 308 and CA8.00oc growing on glycerol, but showed no advantage above $D=0.20 \mathrm{~h}^{-1}$. We conclude therefore that the most suitable mutants for large-scale production are ML308 and CA8.000c when grown under conditions where catabolite repression is small.

The authors thank the Science Research Council for support.

\section{REFERENCES}

Cassio, D., Lawrence, F. \& LaWrence, D. A. (1970). Level of methionyl-tRNA synthetase in merodiploids of Escherichia coli K 12. European Journal of Biochemistry 15, 33 I-334.

Clarke, P. H., Houldsworth, M. A. \& Lilly, M. D. (1968). Catabolite repression and the induction of amidase synthesis by Pseudomonas aeruginosa 8602 in continuous culture. Journal of General Microbiology 51, 225-234.

CLowes, R. C. (1972). Molecular structure of bacterial plasmids. Bacteriological Reviews 36, 36I-405.

DEAN, A. C. R. (1972). Influence of environment on the control of enzyme synthesis. Journal of Applied Chemistry (and Biotechnology) 22, 245-259.

Demain, A. L. (1971). Increasing enzyme production by genetic and environmental manipulations. Methods in Enzymology 22, 86-95.

Gray, P. P., DưNNLL, P. \& LiLLy, M. D. (1972). The continuous flow isolation of enzymes. In Fermentation Technology Today, pp. 347-35I. Edited by G. Terui. Japan: Society of Fermentation Technology.

Goodwin, B. C. (1969). Growth dynamics and synchronization of cells. Microbial Growth. Symposia of the Society for General Microbiology 19, 223-236.

GÜNTHER, H. H., KNORRE, W. A. \& BeRGTER, F. (I969). The possibility of autonomous synchronization of cell division in continuous culture of bacteria. In Continuous Cultivation of Microorganisms, pp. 309314. Edited by I. Málek, K. Beran, Z. Fencl, V. Munk, J. Řičica and H. Smrčková. Prague: Academia.

KNORRE, W. A. (1969). Elucidation of $\beta$-galactosidase formation in continuous culture and by analysis of models with the analogue computer. In Continuous Cultivation of Microorganisms, pp. 225-232. Edited by I. Málek, K. Beran, Z. Fencl, V. Munk, J. Řičica and H. Smrčková. Prague: Academia.

Kontomichalou, P., Mitani, M. \& Clowes, R. C. (1970). Circular R-factor molecules controlling penicillinase synthesis, replicating in Escherichia coli under either relaxed or stringent control. Journal of Bacteriology 104, 34-44.

LANGRIDGE, J. (1969). Mutations conferring quantitative and qualitative increases in $\beta$-galactosidase activity in Escherichia coli. Molecular and General Genetics 105, 74-83.

LEDERBERG, J. (1950). The beta-D-galactosidase of Escherichia coli. Journal of Bacteriology 6o, 38 I-392.

PARDEe, A. B. (1969). Enzyme production by bacteria. In Fermentation Advances, pp. 3-14. Edited by D. Perlman. New York and London: Academic Press.

Perlman, R. L., De Crombrugghe, B. \& Pastan, I. (1969). Cyclic-AMP regulates catabolite and transient repression in E. coli. Nature, London 223, 810-812.

Silverstone, A. E., Arditti, R. R. \& MAGASANIK, B. (1970). Catabolite-insensitive mutants of lac promoter mutants. Proceedings of the National Academy of Science of the United States of America 66, 773-779.

STETSON, H. \& SOMERVILLE, R. L. (197I). Expression of the Tryptophan operan in merodiploid of Escherichia coli. I. Gene dosage, gene position and marker effects. Molecular and General Genetics III, 342-35I.

VoJtíšex, V., SiKYTA, B. \& SLEZÁx, J. (1969). Regulation of the hyperproduction of $\beta$-galactosidase in continuous culture of Escherichia coli $\mathrm{B}$. In Continuous Cultivation of Microorganisms, pp. 215-223. Edited by I. Málek, K. Beran, Z. Fencl, V. Munk, J. Řičica and H. Smrčková. Prague: Academia. 